\title{
PROGRAM PRAKTIK PENGALAMAN LAPANGAN DAN HUBUNGANNYA DENGAN KOMPETENSI MAHASISWA PRODI MANAJEMEN PENDIDIKAN ISLAM FTIK UIN ALAUDDIN MAKASSAR
}

\author{
${ }^{1}$ Ali Nahruddin Tanal, ${ }^{2}$ Muhammad Yahya, ${ }^{3}$ Kamsinah \\ ${ }^{1}$ Institut Agama Islam Negeri Palopo \\ 2Universitas Islam Negeri Alauddin Makassar \\ ${ }^{3}$ Universitas Islam Negeri Alauddin Makassar \\ E-mail: alinahruddintanal@iainpalopo.ac.id
}

\begin{abstract}
This study aims to determine the internship program called PPL implemented by student of Islamic Educational Management Program at UIN Alauddin Makassar, and the relationship between the internship program and the competencies of students involved. This research is classified as field research using quantitative methods. Data were collected using a questionnaire, and analyzed using quantitative descriptive analysis techniques. The productmoment formula is used to test the relationship between the two variables. The results of the data analysis show that the relationship between the intership program and student competency is in a low category, or there is no relationship between the two. Therefore, it was concluded that the field experience program was not relevant to be applied for student of Islamic Educational Management Program who were not in accordance with the competencies of the students.
\end{abstract}

Keywords: Internship Program, Competency

\begin{abstract}
Abstrak
Penelitian ini bertujuan untuk mengetahui pelaksanaan program praktik pengalaman lapangan mahasiswa prodi MPI di UIN Alauddin Makassar, serta hubungan antara program praktik pengalaman lapangan tersebut dengan kompetensi mahasiswa yang terkait. Penelitian ini tergolong penelitian lapangan dengan menggunakan metode kuantitatif. Data dikumpulkan menggunakan angket, dan dianalisis menggunakan teknik analisis deskriptif kuantitatif. Rumus product moment digunakan untuk menguji hubungan dari kedua variabel. Hasil analisis data menunjukkan bahwa $\mathrm{H}_{0}$ diterima, yakni hubungan antara program praktik pengalaman lapangan dengan kompetensi mahasiswa berada pada kategori rendah, atau tidak ada hubungan di antara keduanya. Oleh karena itu, disimpulkan bahwa program praktik pengalaman lapangan tidak relevan diterapkan untuk mahasiswa MPI FTIK UIN Alauddin Makassar yang tidak sesuai dengan kompetensi yang dimiliki oleh mahasiswa.
\end{abstract}

Kata Kunci: Program Praktik Pengalaman Lapangan, Kompetensi

\section{PENDAHULUAN}

Setiap Perguruan Tinggi menyediakan layanan pendidikan pada masing-masing disiplin ilmu atau program studi yang berorientasi pada suatu keahlian dan keterampilan tertentu. Hal tersebut bertujuan agar setelah selesai menempuh perkuliahan di Perguruan Tinggi, seorang lulusan 
akan memperoleh profesi sesuai latar belakang pendidikan yang telah dimiliki di waktu perkuliahan.

Salah satu organisasi dalam naungan Perserikatan Bangsa-Bangsa yang menangani Pendidikan, Ilmu Pengetahuan, dan Kebudayaan, yaitu United Nation Educational, Scientific, and Cultural Organization (UNESCO) merekomendasikan empat pilar pendidikan. Keempat pilar itu adalah 1) learning to know, 2) learning to do, 3) learning to be, dan 4) learning to live together. ${ }^{1}$

Berdasarkan empat pilar di atas dapat kita pahami bahwa pendidikan tidak terbatas pada bagaimana cara membuat peserta didik mengetahui dan memahami suatu ilmu pengetahuan saja, namun juga bagaimana cara mengaplikasikan ilmu pengetahuan tersebut sehingga dapat berguna bagi dirinya dan orang lain. Maka dari itu ilmu pengetahuan yang diperoleh di Perguruan Tinggi dapat bermanfaat secara teoritis dan praktis, sehingga memungkinkan mereka untuk memangku pekerjaan atau jabatan secara profesional.

Menurut Undang-Undang Republik Indonesia Nomor 12 Tahun 2012 tentang Pendidikan Tinggi, Bab I, Pasal 14, Ayat (1); Mahasiswa mengembangkan bakat, minat, dan kemampuan dirinya melalui kegiatan kokurikuler dan ekstrakurikuler sebagai bagian dari proses pendidikan. Sebuah lembaga pendidikan wajib menyediakan sarana dan prasarana pendidikan guna menunjang keberhasilan pendidikan. Sebagaimana yang disebutkan dalam Undang-Undang Nomor 20 Tahun 2003 tentang Sistem Pendidikan Nasional, Bab XII, Pasal 45, Ayat (1); Setiap satuan pendidikan formal dan nonformal menyediakan sarana dan prasarana yang memenuhi keperluan pendidikan sesuai dengan pertumbuhan dan perkembangan potensi fisik, kecerdasan intelektual, sosial, emosional, dan kejiwaan peserta didik. $^{2}$

Setiap lembaga pendidikan baik pada tingkat pendidikan dasar, menengah atau pendidikan tinggi wajib menyediakan sarana dan prasarana yang dibutuhkan peserta didik dalam hal pembelajaran yang berkenaan dengan potensi maupun minat yang dimiliki. Selain itu, penyediaan layanan pendidikan ekstrakulikuler juga wajib disediakan untuk memberikan kesempatan kepada peserta didik untuk memperoleh pengalaman langsung yang dapat menunjang dan mengembangkan ilmu pengetahuan dan keterampilan yang dimiliki peserta didik, sehingga memungkinkan mereka untuk memperoleh kesuksesan kelak di dunia kerja. Sebagaimana yang

\footnotetext{
${ }^{1}$ Tim Pengembang Ilmu Pendidikan FIP-UPI, Ilmu \& Aplikasi Pendidikan: Bagian 1 Ilmu Pendidikan Teoritis (Cet. II; :IMTIMA), h. 1.

${ }^{2}$ Republik Indonesia, “Undang-Undang RI Nomor 12 Tahun 2012 tentang Pendidikan Tinggi” (Jakarta: Dirjen Dikti Kemendiknas, t.th.), h. 133.
} 
tertuang dalam Peraturan Pemerintah Republik Indonesia Nomor 39, Tahun 1992 tentang Peran Serta Masyarakat Dalam Pendidikan Nasional, Bab III, Pasal 4, Ayat (8); Pemberian kesempatan untuk magang dan atau latihan kerja.

Program Pengalaman Lapangan (PPL) Keguruan dan Kependidikan adalah kegiatan akademik yang dilakukan mahasiswa dalam rangka menerapkan dan meningkatkan kompetensi pedagogik, profesional, kepribadian, dan sosial yang mencakup pengetahuan, keterampilan, sikap dan perilaku keguruan dengan segala aspek kependidikan yang dialami secara nyata di sekolah latihan. ${ }^{3}$

Praktik Pengalaman Lapangan (PPL) merupakan bagian kurikuler yang dilaksanakan oleh mahasiswa (calon guru) yang mencakup baik latihan mengajar maupun tugas kependidikan lainnya, secara terbimbing dan terpadu sebagai persyaratan profesi pendidikan. Kegiatan-kegiatan praktik pengalaman lapangan diselenggarakan dalam bentuk pelatihan terbatas, pelatihan terbimbing dan pelatihan mandiri yang diharapkan pada terbentuknya kemampuan keguruan yang terjadwal secara sistematis di bawah bimbingan dosen pembimbing beserta guru pamong. Kegiatan praktik pengalaman lapangan dikhususkan pada kegiatan praktik mengajar (real teaching). Sehubungan dengan kegiatan praktik pengalaman lapangan, mahasiswa terlebih dahulu mengikuti kegiatan Pengajaran Mikro (Micro Teaching). Namun sebagian juga menjelaskan bahwa Pengajaran Mikro (Micro Teaching) terintegrasi di dalam kegiatan praktik pengalaman lapangan.

Pengajaran mikro merupakan pelatihan tahap awal dalam pembentukan kompetensi mengajar melalui pengaktualisasian kompetensi dasar mengajar. Pada dasarnya pengajaran mikro merupakan suatu metode pembelajaran atas dasar kinerja yang tekniknya dilakukan dengan melatihkan komponen-komponen kompetensi dasar mengajar dalam proses pembelajaran sehingga calon guru benar-benar mampu menguasai setiap komponen satu persatu atau beberapa komponen secara terpadu dalam situasi pembelajaran yang disederhanakan...Pengajaran mikro dilakukan di kampus dengan model peer teaching. ${ }^{4}$

\footnotetext{
${ }^{3}$ Fakultas Keguruan dan Ilmu Pendidikan Universitas Serambi Mekkah Banda Aceh, "Buku Pedoman Pelaksanaan Program Pengalaman Fkip-Usm", https://docs.google.com/ document/d/1liU5eRJt EcfgTE_HcZhLH7ynhWHDx_mPGiog8EA9Dg/edit (02 Desember 2015).

4 Pendidikan Guru Sekolah Dasar Universitas Sarjanawiyata Tamansiswa Yogyakarta, "Panduan PPL I PGSD UST", Slideshare.net http://www.slideshare.net/herijunior/panduan-ppl-i-pgsd-ust (02 Desember 2015).
} 
Setelah melaksanakan kegiatan praktik pengalaman lapangan, mahasiswa diharapkan mampu menyelenggarakan pembelajaran di sekolah. Secara khusus, mahasiswa diharapkan kompeten dalam hal-hal berikut:

1. Mengenal secara cermat lingkungan fisik, administratif, akademik, dan sosial sekolah sebagai tempat kerjanya kelak.

2. Mampu menerapkan berbagai kemampuan keguruan secara utuh dan terintegrasi dalam situasi nyata secara terbimbing.

3. Mampu menerapkan berbagai kemampuan keguruan secara utuh dan terintegrasi dalam situasi sebenarnya dengan bimbingan yang minimal atau bahkan mandiri.

4. Mampu menarik pelajaran dari penghayatan dan pengalaman selama latihan melalui refleksi yang merupakan ciri penting pekerjaan profesional.

5. Terampil merencanakan kegiatan pengembangan diri peserta didik secara terpadu.

6. Terampil melaksanakan kegiatan pembelajaran yang mendidik bagi peserta didik.

7. Terampil memberikan layanan bimbingan khusus bagi peserta didik yang membutuhkan. ${ }^{5}$

Jurusan Manajemen Pendidikan Islam (MPI) dengan Program Studi Manajemen Pendidikan Islam (MPI) merupakan salah satu dari empat jurusan dari delapan program studi yang ada pada Fakultas Tarbiyah dan Keguruan UIN Alauddin Makassar. Lulusan sarjana Manajemen Pendidikan Islam nantinya bukan hanya berada pada tataran perencana yang hanya bekerja di belakang meja, tetapi juga memiliki kemampuan dalam hal operasionalisasi di lembaga-lembaga pendidikan (guru dan manajer pendidikan). Maka dari itu, nantinya alumni dari jurusan ini akan banyak membuktikan diri mampu berkompetisi dengan alumni-alumni yang lain.

Sehubungan dengan informasi di atas, pelaksanaan praktik pengalaman lapangan berupa kegiatan mengajar dipandang relevan sebagai bentuk praktik lapangan pada prodi Manajemen Pendidikan Islam. Walaupun terkadang mahasiswa yang melaksanakan praktik pengalaman lapangan juga dapat berperan dalam kegiatan tata usaha sekolah, akan tetapi kegiatan yang wajib dan yang menjadi objek penilaian ialah kegiatan mengajar yang dilaksanakan di kelas, sehingga kegiatan mengajar merupakan hal utama (primer) dan kegiatan tata usaha atau administrasi adalah hal pendukung atau tambahan (sekunder) dalam praktik pengalaman lapangan. Pelaksanaan

5 Lembaga Pengembangan Pembelajaran dan Praktik Lapangan (LP3L) Universitas Kanjuruhan, Pedoman Program Pengalaman Lapangan (PPL) (Malang: LP3L Universitas Kanjuruhan, 2015), h. 2. 
praktik pengalaman lapangan tidak hanya bertolak pada penjelasan di atas. Kita juga perlu memperhatikan dari segi visi dan misi jurusan ini.

Berikut visi dan misi Jurusan Manajemen Pendidikan Islam:

Visi: Wadah pengembangan tenaga kependidikan Islam profesional dan berdaya saing tinggi pada tingkat nasional tahun 2018.

Misi:

1. Membentuk tenaga kependidikan Islam profesional yang memiliki intelektual, emosional, dan intergritas yang tinggi.

2. Membina tenaga kependidikan Islam yang menguasai Teknologi Informasi.

3. Menciptakan tenaga kependidikan Islam yang terampil dan mampu mengaplikasikan ilmunya di masyarakat.

Jika ditelaah kembali dengan memperhatikan visi dan misi di atas, lulusan program studi Manajemen Pendidikan Islam lebih dominan berorientasi pada tenaga kependidikan daripada tenaga pendidik melihat redaksi visi dan misi yang menyebutkan beberapa kali istilah tenaga kependidikan. Sedangkan telah kita ketahui bahwa tenaga kependidikan ialah mereka yang berperan dalam penyelenggara pendidikan, mengurus masalah administrasi, ketatausahaan, dan pengelolaan sekolah, bukan dominan sebagai tenaga pengajar yang aktivitasnya berlangsung di kelas, melaksanakan pendidikan dan pengajaran dan behadapan langsung dengan peserta didik, walau pada dasarnya pendidik juga termasuk dalam tataran tenaga kependidikan. Selain itu, besar kemungkinan jika mahasiswa prodi Manajemen Pendidikan Islam akan mengalami banyak kesulitan dalam mengajar di kelas karena persiapan yang kurang memadai.

Oleh karena itu, perlu dianalisa kembali apakah pelaksanaan praktik pengalaman lapangan yang selama ini dijalankan memiliki korelasi terhadap kompetensi yang dimiliki mahasiswa prodi Manajemen Pendidikan Islam melihat praktik pengalaman lapangan merupakan wadah dalam menerapkan apa yang telah dipelajari mahasiswa itu sendiri, serta apakah melalui kegiatan praktik pengalaman lapangan tersebut dapat menjadi media yang representatif dalam pengaplikasian ilmu pengetahuan, keterampilan dan kompetensi mahasiswa prodi Manajemen Pendidikan Islam Fakultas Tarbiyah dan Keguruan UIN Alauddin Makassar.

Berdasarkan penjelasan di atas, maka peneliti bermaksud untuk mengkaji secara ilmiah mengenai bagaimana kegiatan praktik pengalaman lapangan yang selama ini dilaksanakan oleh mahasiswa prodi Manajemen Pendidikan Islam dan hubungannya dengan kompetensi yang mereka miliki. Apakah kompetensi yang dimiliki mahasiswa prodi Manajemen Pendidikan Islam dalam hal ini manajemen dan pendidikan memiliki hubungan dengan 
keterampilan dasar mengajar mereka yang diterapkan dalam program praktik pengalaman lapangan.

\section{METODE}

Penelitian ini merupakan penelitian lapangan dengan menggunakan metode penelitian kuantitatif. Populasi pada penelitian ini ialah mahasiswa program studi MPI FTIK UIN Alauddin Makassar yang telah mengikuti program praktik pengalaman lapangan. Adapun sampel penelitian ialah 26 orang mahasiswa yang dipilih berdasarkan kesamaan lokasi PPL-nya. Data dikumpulkan menggunakan angket yang ditujukan pada dua variabel. Format angket menggunakan skala Likert dengan empat alternatif jawaban. Data dianalisis menggunakan teknik analisis statistic deskriptif untuk menggambarkan kedua variabel, dan teknik analisis statistik inferensial menggunakan rumus product-moment untuk mengukur hubungan antara kedua variabel. Analisis data dilakukan menggunakan bantuan aplikasi SPSS versi 21.0, Microsoft Excel dan manual.

\section{GAMBARAN KETERAMPILAN DASAR MENGAJAR MAHASISWA SEBAGAI BENTUK PROGRAM PPL}

Berdasarkan hasil penelitian yang telah dilakukan terhadap mahasiswa Prodi Manajemen Pendidikan Islam yang telah melaksanakan praktik pengalaman lapangan di SMA Negeri 11 Makassar dan SMA Negeri 16 Makassar yang terdiri dari 26 mahasiswa, penulis memperoleh data melalui angket yang diisi oleh peserta didik untuk masing-masing mahasiswa prodi Manajemen Pendidikan Islam yang telah melaksanakan praktik pengalaman lapangan, yang kemudian diberikan skor pada masing-masing item soal.

Untuk mengetahui kategori keterampilan dasar mengajar mahasiswa praktik pengalaman lapangan di SMA Negeri 11 Makassar dan SMA Negeri 16 Makassar, dapat diketahui dengan mengkategorikan skor responden. Adapun interval keterampilan dasar mengajar mahasiswa praktik pengalaman lapangan di SMA Negeri 11 Makassar dan SMA Negeri 16 Makassar, yang digolongkan ke dalam 3 (tiga) kategori ${ }^{6}$, dengan perhitungan pada table 1 .

\footnotetext{
${ }^{6}$ Saifuddin Azwar, Penyusunan Skala Psi/kologi ( Yogyakarta; Pustaka Pelajar, 2015), h. 109.
} 
Tabel 1

Kategori Skor Keterampilan Dasar Mengajar Mahasiswa Praktik Pengalaman Lapangan di SMA Negeri 11 Makassar dan SMA Negeri 16 Makassar

\begin{tabular}{|c|c|c|c|c|}
\hline Batas Kategori & Interval & $\begin{array}{c}\text { Frekue } \\
\text { nsi }\end{array}$ & $\begin{array}{c}\text { Kategor } \\
\mathbf{i}\end{array}$ & Persentase \\
\hline $\mathrm{X}<(\mu-1,0 \sigma)$ & $\mathrm{X}<161$ & 2 & Rendah & $7.70 \%$ \\
\hline$(\mu-1,0 \sigma) \leq \mathrm{X}<(\mu+1,0 \sigma)$ & $161 \leq \mathrm{X}<175$ & 19 & Sedang & $73.07 \%$ \\
\hline $\mathrm{X} \geq(\mu+1,0 \sigma)$ & $\mathrm{X} \geq 175$ & 5 & Tinggi & $19.23 \%$ \\
\hline Jumlah & 26 & & $100 \%$ \\
\hline
\end{tabular}

Berdasarkan hasil analisis deskriptif tersebut, dengan memperhatikan 26 mahasiswa sebagai sampel, sehingga diperoleh 2 atau $7.70 \%$ mahasiswa yang barada dalam kategori rendah, 19 atau 73.07\% mahasiswa yang barada dalam kategori sedang, 5 atau 19.23\% mahasiswa yang barada dalam kategori tinggi. Hal tersebut menggambarkan bahwa, keterampilan dasar mengajar mahasiswa praktik pengalaman lapangan di SMA Negeri 11 Makassar dan SMA Negeri 16 Makassar berada dalam kategori sedang.

\section{GAMBARAN KOMPETENSI MAHASISWA PRODI MPI FTIK UIN ALAUDDIN MAKASSAR}

Berdasarkan hasil penelitian yang telah dilakukan terhadap mahasiswa prodi Manajemen Pendidikan Islam mengenai kompetensinya yang berlangsung di Fakultas Tarbiyah dan Keguruan UIN Alauddin Makassar yang terdiri dari 26 mahasiswa, penulis memperoleh data melalui angket yang diisi oleh mahasiswa masing-masing mahasiswa, yang kemudian diberikan skor pada masing-masing item soal.

Untuk mengetahui kategori kompetensi mahasiswa prodi Manajemen Pendidikan Islam, dapat diketahui dengan mengkategorikan skor responden. Adapun interval kompetensi mahasiswa prodi Manajemen Pendidikan Islam, yang digolongkan ke dalam 3 (tiga) kategori ${ }^{7}$, dengan perhitungan sebagai berikut:

\footnotetext{
${ }^{7}$ Saifuddin Azwar,Penyusunan Skala Psikologi ( Yogyakarta; Pustaka Pelajar, 2015), h.
} 109. 
Tabel 2

Kategori Skor Kompetensi Mahasiswa Prodi Manajemen Pendidikan

Islam

\begin{tabular}{|c|c|c|c|c|}
\hline Batas Kategori & Interval & $\begin{array}{c}\text { Frekuens } \\
\mathbf{i}\end{array}$ & $\begin{array}{c}\text { Kategor } \\
\mathbf{i}\end{array}$ & Persentase \\
\hline $\mathrm{X}<(\mu-1,0 \sigma)$ & $\mathrm{X}<60$ & 3 & Rendah & $11.54 \%$ \\
\hline$(\mu-1,0 \sigma) \leq \mathrm{X}<(\mu+1,0 \sigma)$ & $60 \leq \mathrm{X}<70$ & 14 & Sedang & $53.85 \%$ \\
\hline $\mathrm{X} \geq(\mu+1,0 \sigma)$ & $\mathrm{X} \geq 70$ & 9 & Tinggi & $34.61 \%$ \\
\hline Jumlah & & 26 & & $100 \%$ \\
\hline
\end{tabular}

Berdasarkan hasil analisis deskriptif tersebut, dengan memperhatikan 26 mahasiswa sebagai sampel, maka diperoleh 3 atau 11,54\% mahasiswa yang barada dalam kategori rendah, 14 atau 34,61\% mahasiswa yang barada dalam kategori sedang, 9 atau 34,61\% mahasiswa yang barada dalam kategori tinggi. Hal tersebut menggambarkan bahwa, kompetensi mahasiswa Prodi Manajemen Pendidikan Islam berada dalam kategori sedang.

\section{HUBUNGAN PROGRAM PPL DENGAN KOMPETENSI MAHASISWA PRODI MPI FTIK UIN ALAUDDIN MAKASSAR}

Berdasarkan hasil uji $\mathrm{r}$ di atas, diperoleh $r_{\text {hitung }} 0.207$ dengan taraf signifikan 5\% uji dua pihak dk $=\mathrm{n}-2=24$ diperoleh $r_{\text {tabel }} 0.404$, jadi $r_{\text {hitung }}$ $0.207<r_{\text {tabel }}$ 0.404. Ketentuannya bila $r_{\text {hitung }}$ lebih kecil dari $r_{\text {tabel }}$, maka $\mathrm{H}_{0}$ diterima dan $\mathrm{H}_{1}$ ditolak. ${ }^{8}$ Berdasarkan hasil perhitungan di atas dapat disimpulkan bahwa $\mathrm{H}_{0}$ diterima sehingga tidak terdapat hubungan yang positif melainkan hubungannya negatif sebesar 0.207 antara keterampilan dasar mengajar praktik pengalaman lapangan dengan kompetensi mahasiswa prodi Manajemen Pendidikan Islam.

Tabel 3

Interpretasi Koefisien Korelasi

\begin{tabular}{|c|c|}
\hline Interval Koefisien & Tingkat Hubungan \\
\hline $0.00-0.199$ & Sangat rendah \\
$0.20-0.399$ & Rendah \\
$0.40-0.599$ & Sedang \\
$0.60-0.799$ & Kuat \\
$0.80-1.000$ & Sangat kuat \\
\hline
\end{tabular}

Sumber: Sugiyono Metode Penelitian Pendidikan: Pendekatan Kuantitatif, Kualitatif, dan R\&D

\footnotetext{
${ }^{8}$ Sugiyono. Metode Penelitian Pendidikan: Pendekatan Kuantitatif, Kualitatif, dan R\&D. h. 258
} 
Berdasarkan tabel 3 di atas, maka koefisien yang ditemukan sebesar 0.207 termasuk pada kategori yang rendah. Jadi terdapat hubungan yang rendah antara keterampilan dasar mengajar praktik pengalaman lapangan dengan kompetensi mahasiswa prodi Manajemen Pendidikan Islam Fakultas Tarbiyah dan Keguruan UIN Alauddin Makassar. Berhubung penelitian ini menggunakan sampel jenuh dalam hal ini seluruh populasi dijadikan sampel, peneliti tidak menggunakan uji signifikansi hubungan karena sampel merupakan keseluruhan populasi dan hasil dari interpretasi tersebut berlaku untuk semua sampel juga populasi.

Berdasarkan hasil penelitian yang telah dilakukan pada tiga lokasi penelitian, yakni SMA Negeri 11 dan SMA Negeri 16 Makassar untuk variabel program praktik pengalaman lapangan serta Jurusan Manajemen Pendidikan Islam Fakultas Tarbiyah dan Keguruan UIN Alauddin Makassar untuk variabel kompetensi mahasiswa Prodi Manajemen Pendidikan Islam, melalui teknik pengumpulan data menggunakan angket pada kedua variabel yaitu 58 item pernyataan untuk variabel program praktik pengalaman lapangan dan 22 item untuk variabel kompetensi mahasiswa Prodi Manajemen Pendidikan Islam. Kemudian diolah menggunakan teknik analisis data deskriptif dan inferensial.

Setelah dilakukan analisis statistik deskriptif, maka pada variabel pertama ditemukan hasil keterampilan dasar mengajar mahasiswa praktik pengalaman lapangan di SMA Negeri 11 Makassar dan SMA Negeri 16 Makassar berada dalam kategori sedang. Hal ini ditunjukkan dengan diperolehnya $17(65,38 \%)$ dari 26 (100\%) orang mahasiswa yang berada dalam kategori sedang. Sedangkan pada variabel kedua ditemukan hasil mengenai kompetensi mahasiswa Prodi Manajemen Pendidikan Islam Fakultas Tarbiyah dan Keguruan UIN Alauddin Makassar juga berada dalam kategori sedang. Hal ini dibuktikan dengan diperolehnya 14 (34,61\%) dari 26 (100\%) orang mahasiswa yang berada dalam katergori sedang.

Selanjutnya berdasarkan hasil analisis statistik inferensial menggunakan product moment dengan rumus uji $\mathrm{r}$ dalam penelitian ini, maka diperoleh $r_{\text {hitung }}$ 0,207 dan kemudian dengan taraf signifikan 5\% uji dua pihak, dk =n-2 = 24 maka diperoleh $r_{\text {tabel }} 0,404$. Maka dari itu diperoleh $r_{\text {hitung }}$ $0,207<r_{\text {tabel }} 0,404$. Berdasarkan ketentuan, jika $r_{\text {hitung }}$ lebih kecil daripada $r_{\text {tabel }}$ maka $\mathrm{H}_{0}$ diterima dengan kata lain terdapat hubungan negatif atau tidak ada hubungan antara dua variabel, dalam hal ini keterampilan dasar mengajar dalam praktik pengalaman lapangan dengan kompetensi mahasiswa prodi Manajemen Pendidikan Islam Fakultas Tarbiyah dan Keguruan UIN Alauddin Makassar.

Praktik pengalaman lapangan hakikatnya ialah muara penerapan dari semua yang pernah diperoleh di perkuliahan. Praktik pengalaman lapangan 
mencerminkan pengaplikasian semua ilmu pengetahuan mengenai jurusan atau profesi yang ditekuni oleh mahasiswa jurusan ilmu pendidikan dan sejenisnya, di lingkungan kerja yang nyata. Muatan daripada praktik pengalaman lapangan ialah kegiatan mengajar di kelas, oleh karena itu mahasiswa yang akan menjalankan praktik pengalaman lapangan dituntut untuk menguasai keterampilan dasar mengajar sebagai bekalnya dalam mengajar sehingga praktik pengalaman lapangan dapat berjalan dengan lancar.

Keterampilan dasar mengajar adalah keterampilan standar yang harus dimiliki setiap individu yang berprofesi sebagai guru. Menurut Wina Sanjaya, keterampilan dasar ini memuat beberapa komponen di antaranya keterampilan dasar bertanya, keterampilan dasar memberikan penguatan (reinforcement), keterampilan variasi stimulus, keterampilan membuka dan menutup pelajaran dan keterampilan mengelola kelas. ${ }^{9}$ Komponen ini yang akan mengindikasikan bahwa seorang mahasiswa sudah menguasai keterampilan dasar mengajar dan sudah layak untuk mengajar di kelas.

Idealnya ialah penguasaan keterampilan dasar mengajar tersebut sudah dipelajari dan dipraktikkan atau disimulasikan oleh mahasiswa dalam perkuliahan microteaching sebelum pelaksanaan praktik pengalaman lapangan berlangsung agar mahasiswa tidak mengalami hambatan ataupun kesulitan pada aktivitasnya dalam mengajar.

Prodi Manajemen Pendidikan Islam memiliki target kompetensi lulusan yang dicita-citakan. Pencapaian hal tersebut sudah pasti sangat berhubungan dan dipengaruhi oleh prosesnya. Konsep utama program studi manajemen pendidikan Islam ialah menghasilkan lulusan yang dapat berprofesi sebagai tenaga kependidikan (manajer) dan juga sebagai pendidik (guru). Untuk mencapai hal di atas tentunya harus disediakan semua hal yang berkenaan dengan hal tersebut, seperti kurikulum program studi, fasilitas, tenaga pendidik, dan sebagainya yang dianggap relevan. Berbicara mengenai kurikulum yang muatannya adalah mata pelajaran atau mata kuliah yang disediakan, jika dikaitkan dengan praktik pengalaman lapangan maka praktik pengalaman lapangan yang hakikatnya adalah sebagai muara harus dapat menjadi media yang mewakili semua mata kuliah, khususnya mata kuliah keahlian khusus dalam hal penerapannya.

Kedudukan praktik pengalaman lapangan ialah sebagai program yang memiliki SKS (sistem kredik semester) sama dengan mata kuliah lainnya. Akan tetapi dalam hal tujuan, praktik pengalaman lapangan ialah sebagai media bagi mahasiswa untuk mengaplikasikan ilmu pengetahuannya dalam

${ }^{9}$ Wina Sanjaya, Strategi Pembelajaran Berorientasi Standar Proses Pendidikan, h. 3435. 
mengajar. Jika diperhatikan mengapa Prodi Manajemen Pendidikan Islam melaksanakan praktik pengalaman lapangan mungkin karena Prodi ini bernaung di bawah Fakultas Tarbiyah dan Keguruan yang dominan program studinya berorientasi untuk menjadi guru, atau mungkin belum sempat terpikirkan bahwa dibutuhkan bentuk program praktik khusus untuk prodi Manajemen Pendidikan Islam, hingga pada akhirnya sudah muncul berita bahwa untuk tahun ajaran selanjutnya (2016), mahasiswa Prodi Manajemen Pendidikan Islam akan melaksanakan praktik kerja lapangan (PKL) sebagai pengganti praktik pengalaman lapangan dan dianggap lebih relevan.

Kembali pada pembahasan awal mengenai hubungan antara praktik pengalaman lapangan dengan kompetensi mahasiswa Prodi Manajemen Pendidikan Islam. Setelah memperhatikan konsep kompetensi lulusan mahasiswa Prodi Manajemen Pendidikan Islam, sudah langsung disimpulkan bahwa ada hubungan antara praktik pengalaman lapangan dengan kompetensi mahasiswa Prodi Manajemen Pendidikan Islam karena dalam redaksinya sudah dijelaskan bahwa prodi ini juga diorientasikan untuk menjadi guru dan mahasiswa Prodi Manajemen Pendidikan Islam juga diajarkan mata kuliah microteaching saat perkuliahan. Namun tentu dari segi persiapan dalam hal ini perkuliahan hingga pada tahap praktik pengalaman lapangan, dapat dilihat apakah ilmu pengetahuan yang diperoleh mahasiswa di waktu perkuliahan diterapkan di program praktik pengalaman atau tidak.

Untuk itu pengkajian lebih lanjut mengenai hubungan antara dua hal tersebut perlu dilakukan lebih lanjut. Setelah menelusuri dan mengkaji mengenai bagaimana keterampilan dasar mengajar mahasiswa Prodi Manajemen Pendidikan Islam dalam melaksanakan praktik pengalaman lapangan serta bagaimana kompetensi mahasiswa Prodi Manajemen Pendidikan Islam yang sesungguhnya, dan menyajikannya ke dalam bentuk data statistik, kemudian menguji hubungan (product moment) kedua variabel dengan menggunakan rumus statistik, hingga akhirnya menemukan hasil dan kesimpulan.

Menurut pada keterangan hasil penelitian di atas, peneliti menginterpretasikan bahwa hubungan antara program praktik pengalaman lapangan dengan kompetensi mahasiswa Prodi Manajemen Pendidikan Islam berada dalam kategori rendah, dengan kata lain tidak ada hubungan yang kuat atau signifikan antara praktik pengalaman lapangan dalam hal ini penguasaan kompetensi dasar mengajar dengan kompetensi dalam hal ini keahlian dan keterampilan yang dimiliki oleh mahasiswa Prodi Manajemen Pendidikan Islam yang diperoleh berdasarkan pendidikan dan pengajaran pada waktu perkuliahan. Hal terpenting ialah program praktik pengalaman lapangan kurang relevan untuk menjadi media atau sarana praktikum mahasiswa Prodi Manajemen Pendidikan Islam, serta program praktik 
pengalaman lapangan tidak dapat menjadi media yang representatif untuk mahasiswa Prodi Manajemen Pendidikan Islam dalam mengimplementasikan ilmu pengetahuan dan keahliannya dalam hal manajemen.

Seiring dengan hal itu, rencana mengenai akan dilaksanakannya program praktik kerja lapangan (PKL) pada angkatan selanjutnya untuk Prodi Manajemen Pendidikan Islam yang pernah dikemukakan oleh Ketua dan Sekretaris Jurusan Manajemen Pendidikan Islam dianggap langkah yang tepat sebagai pengganti praktik pengalaman lapangan yang selama ini telah dilaksanakan mahasiswa Prodi Manajemen Pendidikan Islam sebelumnya. Tentunya untuk mengetahui efektivitas dan produktivitas program tersebut, harus senantiasa dilakukan pengawasan dan evaluasi dalam bentuk kajian atau penelitian semacam ini, sehingga visi, misi, tujuan hingga pada sasaransasaran operasional jurusan dapat tercapai sesuai dengan apa yang telah direncanakan.

\section{PENUTUP}

Berdasarkan hasil penelitian pada program praktik pengalaman lapangan dan kompetensi mahasiswa, serta hubungannya, maka dapat disimpulkan bahwa keterampilan dasar mengajar mahasiswa yang telah melaksanakan praktik pengalaman lapangan di SMA Negeri 11 Makassar dan SMA Negeri 16 Makassar berada dalam kategori sedang. Hal ini dibuktikan dengan terdapatnya 65,38\% mahasiswa yang barada dalam kategori sedang. Kompetensi mahasiswa Prodi Manajemen Pendidikan Islam berada dalam kategori sedang. Hal tersebut dibuktikan dengan hasil analisis deskriptif tersebut, dengan memperhatikan dari 26 mahasiswa, terdapat 14 atau $53,85 \%$ mahasiswa yang barada dalam kategori sedang.

Berdasarkan uji product moment koefisien yang ditemukan sebesar 0,224 termasuk pada kategori yang rendah. Jadi terdapat hubungan yang rendah antara keterampilan dasar mengajar dalam praktik pengalaman lapangan dengan kompetensi mahasiswa Prodi Manajemen Pendidikan Islam Fakultas Tarbiyah dan Keguruan UIN Alauddin Makassar. Berdasarkan ketentuan, jika $r_{\text {hitung }}$ lebih kecil daripada $r_{\text {tabel }}$ maka $\mathrm{H}_{0}$ diterima dengan kata lain terdapat hubungan negatif atau tidak ada hubungan antara dua variabel, dalam hal ini keterampilan dasar mengajar dalam praktik pengalaman lapangan dengan kompetensi mahasiswa Prodi Manajemen Pendidikan Islam Fakultas Tarbiyah dan Keguruan UIN Alauddin Makassar.

Sehubungan dengan hasil penelitian sebaiknya suatu lembaga pendidikan PTAIN atau sejenisnya menyediakan layanan yang relevan, sesuai dengan kebutuhan, minat dan keterampilan mahasiswa pada masing-masing program studi. Sebaiknya pula dilakukan benchmarking pada lembaga pendidikan sejenis yang dianggap berhasil dan memiliki mutu pendidikan 
terbaik. Terutama dalam hal penyediaan sarana praktik, layanan administrasi dan kurikulum.

\section{DAFTAR PUSTAKA}

Azwar Saifuddin,Penyusunan Skala Psikologi, Yogyakarta: Pustaka Pelajar, 2015.

Fakultas Keguruan dan Ilmu Pendidikan Universitas Serambi Mekkah Banda Aceh, "Buku Pedoman Pelaksanaan Program Pengalaman Fkip-Usm", https://docs.google.com/ document/d/1liU5eRIt EcfgTE HcZhLH7ynhWHDx mPGioq8EA9Dg/edit, 02 Desember 2015.

Lembaga Pengembangan Pembelajaran dan Praktik Lapangan (LP3L) Universitas Kanjuruhan, Pedoman Program Pengalaman Lapangan (PPL), Malang: LP3L Universitas Kanjuruhan, 2015.

Pendidikan Guru Sekolah Dasar Universitas Sarjanawiyata Tamansiswa Yogyakarta, "Panduan PPL I PGSD UST", Slideshare.net http://www.slideshare.net/herijunior/panduan-ppl-i-pgsd-ust, $\quad 02$ Desember 2015.

Republik Indonesia, “Undang-Undang RI Nomor 12 Tahun 2012 tentang Pendidikan Tinggi", Jakarta: Dirjen Dikti Kemendiknas, t.th.

Sanjaya, Wina. Strategi Pembelajaran Berorientasi Standar Proses Pendidikan, Jakarta: Kencana, 2013.

Sugiyono. Metode Penelitian Pendidikan: Pendekatan Kuantitatif, Kualitatif, dan R\&D. Bandung: Alfabeta, 2015.

Tim Pengembang Ilmu Pendidikan FIP-UPI, Ilmu \& Aplikasi Pendidikan: Bagian 1 Ilmu Pendidikan Teoritis, Cet. II; :IMTIMA. 
48 | Ali Nahruddin Tanal, Muhammad Yahya, Kamsinah

HALAMAN INI SENGAJA DIKOSONGKAN 